\title{
Mapping a New Geography of Space and Power
}

Nicole Fabricant

Towson University

\begin{abstract}
In this paper, I analyze the ways in which MST-Bolivia (Movimiento Sin Tierra) forged a national-level movement through one counter-hegemonic event: the Fifth Indigenous March for Land and Territory, which originated in Santa Cruz de la Sierra in October 2006. This march enacted a powerful performance of panindigenous solidarity and nationalistic sentiment which led to a public declaration by president Evo Morales to approve the New Agrarian Reform Law. I focus in particular on the organizational and spatial structure of the march, and on the significance of seizing public space in protest.

Keywords

Agrarian Revolution, Fifth Indigenous March for Land and Territory, INRA Law, MST Mobilizations, New Agrarian Reform Law, Politics of Food, Radical Politics of Land Redistribution, Reinvention of Space
\end{abstract}




\section{REVISTA DE ESTUDIOS BOLIVIANOS}

\section{Resumen}

En este trabajo analizo cómo el MST-Bolivia (Movimiento Sin Tierra) forjó un movimiento de alcance nacional a través de un evento contra-hegemónico: la Quinta Marcha Indígena por la Tierra y el Territorio, originada en Santa Cruz de la Sierra en octubre de 2006. Esta Marcha articuló un poderoso performance de solidaridad y nacionalismo pan-indígena que llevó al Presidente Evo Morales a declarar públicamente la aprobación de la Ley de Reconversión Comunitaria de la Reforma Agraria. En mi trabajo me enfoco particularmente en la estructura organizativa y espacial de la Marcha como también en los efectos que produce la toma del espacio público en signo de protesta.

Palabras claves

Ley INRA, Movilizaciones del MST, Nueva Ley de Reforma Agraria, Política de la Comida, Políticas Radicales de Redistribución de la Tierra, Quinta Marcha Indígena por la Tierra y el Territorio, Reinvención del Espacio, Revolución Agraria

\section{Public Declaration of Agrarian Revolution}

On a steamy Saturday in early June 2006, on a day when Evo Morales launched his Agrarian Revolution to take back latifundio land [large haciendas] and redistribute it to landless peasants, thousands of indigenous campesinos, peasants, and agricultural laborers (many dressed in ripped t-shirts, cotton slacks, and abarcas) congregated around a small stage, close to the Chiriguano monument in Santa Cruz, Bolivia. Some of the protesters wrapped themselves in wiphala flags, ${ }^{1}$ while others carried the blue and white MAS [Movimiento al Socialismo] banner. Still others had created their own signs made of cheap cardboard paper, sticks, and stones; some read: Tierra es Vida [Land is

\footnotetext{
${ }^{1}$ This colorful flag represents the distinct indigenous nations.
} 


\section{REVISTA DE ESTUDIOS BOLIVIANOS}

Life] or No a la mercantilización de la Tierra [Stop Privatizing Land]. An MST [Movimiento Sin Tierra] organizer waved his MAS flag with one hand, while his other limp arm hung by his side ${ }^{2}$. He declared, "It is our right to own land. We live on the land; our parents lived on the land. This is our life -to work, to produce from the land for our families and for the city. We have to work to survive" (Ponciano Sulka. Personal interview. June 30 2006). ${ }^{3}$

As people congregated around the stage, the clouds rolled in, hanging heavily above the crowd as the sky turned a dark bluish gray. Occasionally, military planes flew overhead to keep an eye on the protesters, their engines emitting an eerie whine as they passed. I stood with Deysi, an MST organizer who was dressed de pollera [traditional indigenous layered skirt], Margarita, Ponciano Sulka's daughter, and another compañera [comrade] from MAS. Hugo Salvatierra, then Minister of Agriculture, spoke for a few minutes about the historic significance of this day: "For more than 500 years you have been oppressed, your land taken away, your communities and livelihood destroyed. But now, it is time for you to turn the tables." The protesters shouted their agreement in Quechua, "Jallalla Hermano!" [yes, brother]. He in turn yelled in Spanish about the importance of the Agrarian Revolution for decolonizing Bolivia, and the crowd cheered in Quechua, "Jallala!"

Suddenly, the crowd split into two large groups and started chanting, "EVO, EVO, EVO! The pueblo is with you." Evo Morales, dressed for the occasion in an Andean shawl and colorful button-down shirt, welcomed everyone. "I would like to thank all the organizations, social movements, and farm worker unions. We should also welcome the enemies of Santa Cruz as well. They are not happy because we are waking up this country with a new form of governance. This form of governing, our form of governing, is making history."

Evo Morales presented land titles to 60 indigenous communities from different parts of Bolivia. He gave titles representing more than 7.5

\footnotetext{
${ }^{2}$ MST-Bolivia borrows its name from the more well-known Brazilian Landless Movement, which is the largest social movement in all of Latin America, with an estimated 1.5 million landless organized in 23 out of the 27 states.

${ }^{3}$ All translations from Spanish to English are mine.
} 
million acres to small-scale farming communities in the departments of Beni, Cochabamba, La Paz, Oruro, Pando, Santa Cruz, and Tarija. ${ }^{4}$ He also promised the demonstrators that Bolivia's 2.5 million rural poor would receive titles to 20 million additional hectares of land over the next five years. His guarantee meant that 13 percent of the land would be given to about 28 percent of the population. Nearly one-third of the land targeted for redistribution was already owned by the state, while another two-thirds would be reclaimed from individuals or companies holding large amounts of land in the Oriente with no legal title. He declared that those who owned property legally and used land productively would not be affected, but those who had received property or obtained titles illegally through political ties to military dictators would forfeit their land.

Without warning, the rain began. Despite the downpour, however, the protesters remained at the Chiriguano statue, ${ }^{5}$ fixed in space and mesmerized by Evo's public performance. As one MST organizer declared at the rally, "Evo is with us. He is with the poor indigenous majority. Such an event in the most conservative city of Bolivia, Santa Cruz, illustrated not only to us but to the entire nation his intention to implement laws that would benefit us, the working class and the poor of this country" (Silverio Vera. Personal interview. June 3 2006). Suddenly, as if they were his last and final words, he shouted in the midst of the torrent, "The great land owners of the Oriente are crying. They are hysterically crying because they know that their glory days are over... we will seize their unproductive land and give it to poor campesinos."

\footnotetext{
${ }^{4}$ The legal titles given out by Morales had been lying dormant in the government offices of INRA, the National Institute for Agrarian Reform, for up to ten years, a sign of the snail's pace at which agrarian reform has taken place in Bolivia. Some re-titling has occurred, mainly Tierras Comunitarias de Origen or TCOs in the eastern and lowland areas of Bolivia, through a third party process that hires private companies to perform legal and technical evaluations of agrarian files, field tests, geographic referencing, etc. The re-titling process has taken place, while ignoring the INRA global framework, which provides for a simultaneous process of expropriation, reversal and redistribution.

${ }^{5}$ The Chiriguano statue was actually erected in the mid-1990s by elites of Santa Cruz -it was an effort to illustrate their solidarity and comraderie with the indigenous peoples of the Oriente. More recently, the statue has been used by Evo Morales and the MAS administration in order to gather people in protest -an act of reclaiming such a space.

${ }^{6}$ Evo Morales' speech. June 2006.
} 


\section{REVISTA DE ESTUDIOS BOLIVIANOS}

Morales's Agrarian Revolution ${ }^{7}$ altered Gonzalo Sánchez de Lozada's land reforms of 1996. Such reforms included the passing of Law 1715, or Ley INRA [Instituto Nacional de la Reforma Agraria], which was an attempt to undo the corruption of previous military dictators. The law, however, has been ineffective. The goal of INRA was to redistribute state-owned lands, as well as land obtained through corruption, to the landless. Instead of redistributing land to peasants, however, the law served only to benefit the wealthy by implementing low taxes for those who owned multiple plots. In the words of an MST leader, "The law has been manipulated so that the land is not for those who work it, but for those who pay the taxes. ${ }^{8}$ It benefits the rich." Low taxes also opened the possibility for legalized absentee ownership, speculation, and accumulation of thousands of hectares. At the same time, the INRA process became increasingly bureaucratic, lengthy, and costly, while failing to respond to the intensifying demand for the allocation of land to campesinos (Urioste 1).

\footnotetext{
${ }^{7}$ Evo Morales' Agrarian Revolution sought to alter the structure of production and the way of life in rural areas through the passing of seven decrees. He declared a state of emergency in regard to the immediate titling of fiscal lands. All of the state owned land would be immediately handed over to indigenous people and small-scale farmers.

${ }^{8}$ In "Restructuring citizenship in Bolivia: El Plan de Todos," Benjamin Kohl argues that the 1996 Agrarian Reform Law or INRA law, offers an excellent illustration of the contradictory impacts that neoliberal policies promoted by Gonzalo Sánchez de Lozada's administration had on citizenship rights. The law protects campesino and indigenous land, while at the same time promoting the redistribution of agricultural land through the creation of efficient markets. The law seeks to guarantee the rights of campesino and indigenous communities through exempting subsistence farmers from paying taxes and granting titles to eight indigenous territories. At the same time, however, it offers a fundamental protection to large landowners who can only lose their land if they abandon their property. Previously, the government considered idle land to be abandoned while the new law considers land abandoned when the owner fails to pay taxes on it. This has allowed or set the precedent for absentee landowners to protect their holdings by paying $1 \%$ of the value that they themselves establish. Someone who owns 50,000 hectares could assess their own land at $\$ 20,000$ and therefore pay an annual tax of only $\$ 200.00$ (Solón 19). This self-assessment provision of the INRA has turned one of the fundamental principles of the 1952 Agrarian Revolution from 'land to the tiller' to that of 'land to the taxpayer' (Kohl).
} 


\section{REVISTA DE ESTUDIOS BOLIVIANOS}

In order to modify the failed Ley INRA, Morales convened a commission of popularly elected delegates from distinct social movements to draft the new legislation. In the words of MST organizer, Silvestre Saisari:

The political climate in September was tense. We had already written the seven articles of the New Agrarian Reform Law. We were working on a draft of the proposal. In mid-September, we presented the draft to the executive branch. In October, Morales sent the new legislation to the Congress, where it passed through the Chamber of Deputies. But then, it was held up in the Senate where the right-wing opposition party, PODEMOS, had the majority vote by one. They tried to create some concessions before passing the law. Their proposal was that the law should not include the reversion and expropriation of latifundio land. They wanted to simply redistribute state lands to peasants. Instead of creating solutions to the problem, they were creating more problems (Silvestre Saisari. Personal interview. July 20 2007).

Furthermore, the Eastern Agricultural Chamber announced that they would create armed defense committees to protect their land against groups of peasants. Sporadic incidents of violence directed toward indigenous campesinos flared in the city of Santa Cruz during the summer months. By October 2006, the draft of the bill was still sitting on the floor of the Senate, but the right-wing members of PODEMOS refused to pass the new legislation. MST and other campesino organizations decided to take matters into their own hands and march from Santa Cruz to La Paz, in order to defend the position that land "should belong to those who work it" and pressure the government to pass redistributive 


\section{REVISTA DE ESTUDIOS BOLIVIANOS}

legislation." 9

Understanding how the landless peasants built a national-level movement through time and space demands a grasp of the 28-day march for land and territory. ${ }^{10}$ In the words of the MST leader quoted above, the march began "as a lowland indigenous march," then found new supporters as "other groups from the valleys and altiplano realized the importance of such a protest and they, too, joined." Through the march, indigenous people sought to reclaim space (in the form of land and territory) for themselves. If we think of space as a "system of containers of social power," as Foucault has argued, then the accumulation of capital and social power is directly linked to social and physical geographies. Through the processes of deterritorialization and reterritorialization (Deleuze and Guattari 1984), poor people across the globe become movable and disposable, and deep social networks and communities are disrupted and destroyed, all in the interests of capital. As David Harvey suggested, "accumulation by dispossession includes the commodification and privatization of land and the forceful expulsion of peasant populations" (Harvey 145).

\footnotetext{
${ }^{9}$ There have been four previous national-level indigenous campesino mobilizations for land and territory. In 1990, 600 indigenous people from Beni marched 800 kilometers from the lowlands to the highlands to demand recognition of indigenous lands. This dramatic "Marcha por el Territorio y la Dignidad" was covered by media and achieved public awareness for Bolivia's lowland peoples as citizens seeking property rights. In response, President Paz Zamora signed Supreme Decree 22611, which created four multi-ethnic indigenous territories. The 1990 march was a single-issue protest not based on historic class alliances. Its political aim was preserving the environment and protecting natural resources. In 1996, the "Marcha por el Territorio, el Desarrollo y la Participación Política de los Pueblos Indígenas" took place. This mass mobilization led to the passing of the INRA law under Sánchez de Lozada's administration. In 2000, indigenous people's of Beni called another march (Marcha por la Tierra, el Territorio y los Recursos Naturales) protesting the slow action on TCOs, and the president sent emissaries to assure the community that concessions would be made. Finally, the 2002 "Marcha por la Soberanía Popular, el Territorio y los Recursos Naturales" combined indigenous and social movements that marched from Santa Cruz to La Paz.

${ }^{10}$ In the case of Bolivia, recent discussion of the land problem is more closely related to the two aspects of territory: land and territory as productive resources and as political autonomy. They are demanding a strengthening of the right of indigenous peoples, rural farming and native communities to manage and exploit their renewable and non-renewable natural resources, as well as the redefinition of local and regional territorial jurisdictions (Pacheco y Valda 2003).
} 


\section{REVISTA DE ESTUDIOS BOLIVIANOS}

Struggles to reconstitute power relations are often, implicitly or explicitly, daily battles to reorganize the spatial boundaries between those with and those without power. From time to time, individual or sporadic forms of resistance in space can coalesce into coherent social movements with the aim of liberating space and time from their current configurations, thus constructing an alternative vision of society -a vision in which values, time, space, and money are understood in new and distinct ways (Harvey 239). This is precisely what MST sought to do through their mass mobilization: "Our movement through national space was critical to the building of social relationships and political alliances; we consolidated our alliances with the pueblos indígenas. And through such alliances we began to debate, critique, and offer solutions to the problem of land inequality in our country" (Saisari).

The following questions, then, prove critical to a spatial analysis of politics. As multinational firms search for new frontiers into which they can expand, how do oppositional movements use space, infuse it with meaning, and eventually reterritorialize as a critical strategy of resistance? Ultimately, how does a movement's reclaiming of spaces (regional, national, rural, and urban) assist in the building or shaping of alternative visions of land use and appropriation?

In this paper, I analyze the ways in which MST, through time and space, forged a collective identity through one event, the Fifth Indigenous March for Land and Territory. I focus in particular on their movement in columnas [columns], the organizational and spatial structure of the march that influenced the construction of meaningful relationships between MST members. The march coordinators organized participants into columnas, which reflected MST núcleo, community, and regional base. As participants walked and talked in these columnas, they began to share stories of struggle and sacrifice. Such relations were further deepened through particular eating rituals. As MST stopped in specific locations along the way to eat, they transported the idea of an olla común [communal pot] by setting up a collective pot on the side of roads or in peripheral city spaces in order to feed and nourish the movement. Through the very act of preparing a meal and eating, MST built collective ideology, taught principles and ideals of the movement, and reinforced the improvisational character of political rituals and traditions to organization members. Finally, I explore the significance of seizing public space in protest. MST occupied several plazas as they moved through the national landscape, thus reterritorializing and transforming everyday 


\section{REVISTA DE ESTUDIOS BOLIVIANOS}

spaces into sites of resistance. The most symbolic of all plaza occupations occurred in La Paz, where 30,000 indigenous people and campesinos took over the Plaza Murillo and demanded legislative change. With their tents, pots and pans, and sleeping bags, they refused to leave the plaza until the New Agrarian Law was passed.

\section{Organizational Structure of MST Mobilizations}

MST's organizational structure or praxis draws on the practices of ecclesiastical base communities (CEBs) promoted by liberation theologians, who believed that through a particular organizational structure, poor people could become the protagonists of their own liberation. ${ }^{11}$ Based upon such a model of liberation, MST at the local level breaks down into ten to twenty núcleos, or small community groups, in which individuals reflect upon the social realities of their communities and organize to create material and structural change. Within the núcleo, distinct members participate in commissions that study and address issues such as education, health, communication, and safety. Such commissions are decentralized, allowing the organization to function in a cohesive, yet flexible manner. This same model is applied to the state and national levels, where leaders specializing in land and territory, education, and health come together to comprise the larger decision-making body.

The coordinators of the march adopted this mobile organizational structure, which also proved critical to the ideological and political development of the movement through time and space. A horizontal

\footnotetext{
${ }^{11}$ This is particularly important, considering new forms of exploitation and slavelabor conditions in the Santa Cruz region. Sub-contractors actively recruit the poorest and most disenfranchised to work in the sugar cane industry. Some of the sub-contractors say that highland Indians from the rural areas of Potosí make the best cutters, "They are hard workers and quiet or submissive" (Juan Mamani. Personal interview. August 15 2007). Such-subcontractors give potential workers an advance on their future salaries in order to solidify the labor deals. Once the workers have taken cash advances, they are locked into a system of debtpeonage, obliged to work for that contractor for no benefits, under exploitative conditions, and for low wages. The fact that the sub-contractor is not hired by the company also allows the company to claim that they are not responsible for the use of forced labor and that it does not have the employer's duties in relation to labor rights, health care, and other benefits.
} 


\section{REVISTA DE ESTUDIOS BOLIVIANOS}

structure of leadership enabled a cross-section of MST regional memberships to participate in commissions covering distinct issues pertinent to the 28-day march, such as food, health, communication, and safety. These commissions met every evening as a national-level body to discuss the progress of the New Agrarian Reform Law, the state of participants' health, and the safety of demonstrators. They worked collaboratively to create a supportive environment in which members exchanged ideas, debated, and eventually made decisions regarding the advancement of the March. As Arjun Appadurai (2002) argues in an article on neighborhood organizations and coalitions in Mumbai, social movements concerned with consciousness changing and self-mobilization can inculcate protocols that cultivate a non-hierarchical, antibureaucratic, and anti-technocratic organizational style.

MST's horizontal structure of leadership allowed for more equal participation and opportunity, fostering the building of political relationships, and promoted a quicker transmission of information from rank and file to organizational committee.

The commissions were a space in which to exchange experiences and ideas. I participated in the work group called Politics. We had meetings every evening, in which everyone sat on the floor of a large coliseum or gymnasium. There was no particular leader; we all led discussions as a group "pidiendo la palabra," or asking to take the floor. We had to know the proposal for Agrarian Reform Law inside and out; we debated the proposal and discussed the implementation. Then, we would meet with our regional groups or bases in order to transmit information from the national level decision-making body to the bases (Rosalita Suárez. Personal interview. July 22 2007).

It is important to note, however, that such a horizontal structure of leadership is not without its own contradictions. Some MST rank-and-file members asserted that the horizontal leadership was ineffective. Many community representatives who prided themselves on a sindicato [unionstyle] background, refused to accept such a non-bureaucratic structure. They often assumed leadership roles and made decisions for their particular community bases, as opposed to deferring to or consulting 


\section{REVISTA DE ESTUDIOS BOLIVIANOS}

with the appropriate committee members. One example of this occurred when Juan Carlos Vedia, the regional leader of Obispo Santiesteban, decided to search independently for food and hoard these goods solely for his community, instead of abiding by the rules of the food commission. When MST comrades found out about such dissenting behavior, they strongly opposed it, and forced Vedia to make a statement publicly to the movement about his actions. His hoarding of food breached the norm, fiery conversations followed, and eventually a solution $^{12}$ was proposed: either abide by the rules or march as a separate unit. Such an organizational style, by and large, creates a more democratic form of leadership, as community members are held accountable for their actions.

\section{Spatializing the March into Columnas or Base Communities}

While the organizational structure created a decentralized governing body, the spatial organization ${ }^{13}$ of MST members into columnas also proved critical to understanding the evolution of social and political relationships over the 28 -day period of the march. These columnas included lines of two or three people across (members from the same núcleo) and many rank-and-file members following step. Columnas serve multiple purposes in Latin American protest marches: they organize people in space to create an orderly demonstration, serve as a human wall protecting the masses from police brutality, and can bring traffic to a standstill. Importantly, there is a disciplined precision practiced by members as they maintain five to six inches of distance between each other while marching in columns. Many say that this is about disciplina -the importance of maintaining a permanent position in space and a

\footnotetext{
${ }^{12}$ Sometimes MST participates in Justicia Comunitaria. This is an Andean tradition of community justice, where people decide on the actual punishment, which can include violent acts such as lynching dissenting members.

${ }^{13}$ Much anthropological work has focused on how the conceptual and material dimensions of space are central to the production of social life (Bourdieu 1977, de Certeau 1984, Lefebvre 1991). At the same time, though, social movement theorists have looked at how movements operate not only in, but more importantly on, with, and in relation to space (Castells, Miller, Brown, Staeheli, among others). Yet, little scholarly work has focused on the spatial dynamics or organization of physical bodies in space as critical to understanding the building of movement politics (see Wolford 2000).
} 


\section{REVISTA DE ESTUDIOS BOLIVIANOS}

semi-synchronized step pattern, i.e. not falling too far behind the person in front.
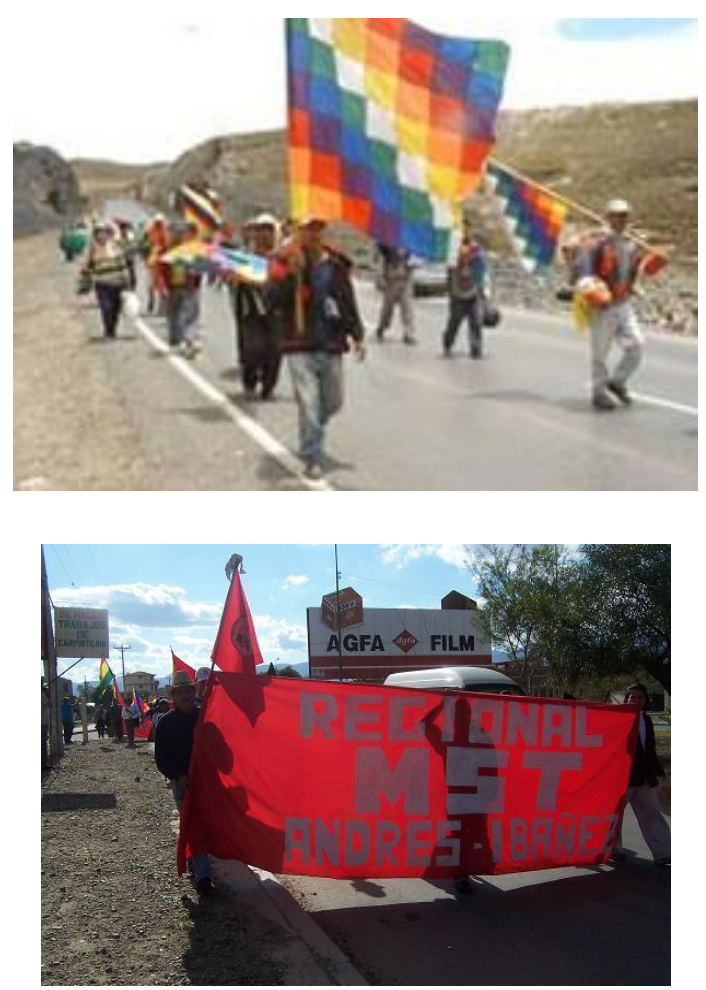

MST-Bolivia organized into Columnas in Sacaba, eight to ten miles outside the city of Cochabamba Source: author's archive

Unlike their working lives on large plantations, which separated skilled and unskilled laborers from one another, the spatial structure of the landless march stressed the importance of non-hierarchical ordering in space. When asked about his life on a sugarcane plantation, one demonstrator remarked: 


\section{REVISTA DE ESTUDIOS BOLIVIANOS}

We are in the worst position [referring to unskilled laborers]; we live on the far end of the plantation in small, makeshift houses, while the full-time workers live in more permanent structures, closer to the center plantation. We can easily be replaced by someone else. This is why we just try to do our job, not really talk much to the other cane cutters (Daniel Ortega. Personal interview. Oct. 15 2006).

While sugarcane contractors separated full-time workers from temporary laborers, preventing any form of communication, the columna structure, in some ways, paralleled the reciprocal nature of work groups in ancient Andean rural communities. According to John Murra (1975) and his students, the Inca state, unlike the Aztecs, operated without markets; instead, it was organized around principles of ayni (reciprocal exchange) and minka (redistribution and/or corvée labor). Such forms of collective labor survived in modified form well into twentieth century, despite steady incursions of the market (Weismantel 2006). Mayer and other researchers compiled detailed documentation of workday exchanges in which reciprocal relations (labor services, ceremonial exchanges) continue to exist alongside barter and cash purposes. He noted that reciprocal relations prevail in several highland communities in Peru during periods of intensive production because of its symmetric, egalitarian nature, which increases output. Once the crops, however, reached maturity and consumability, the ayni-based regime of collective labor shifts into a system of highly individualized storing system in which each household serves as a form of private property (Mayer 2002). Whether in rural Andean communities or walking in columas on a march to La Paz, there is a flexibility and malleability to such organizational structures.

While many social scientists have written about highland agrarian social and working relations, many protesters did not make the explicit connection between their agrarian working lives and their political ones. However, it is apparent that such columnas, or base communities, created the possibility for the construction of networks of solidarity and the hope that such reciprocal relationships could be transported back to their communities. 


\section{REVISTA DE ESTUDIOS BOLIVIANOS}

The spatial structure and organization, in conjunction with the daily struggles on the journey, created an environment ripe for the formation of social support networks. "It was great; we really got to know people well along the march - we had the time to share stories and ideas" (Eulogio Cortés. Personal interview. August 25 2007). Much anthropological work has looked at the ways in which poor people, living in dire economic circumstances; forge informal care or exchange networks in order to survive. ${ }^{14}$ The march figured in MST members' lives as a month-long sacrifice, demanding physical endurance. The blazing afternoon sun and heat, the lack of food and water, and the minimum supply of medicine created arduous walking conditions. In addition, many participants did not have appropriate clothing or footwear for such a journey; many had nothing more than their abarca sandals. The straps from their leather sandals rubbed against their skin, creating sores and open wounds on already calloused feet. The lack of appropriate attire and the need for critical medical services caused walking partners to worry about the people traveling next to them:

There were families that came from very, very far - they left their homes without anything, just the clothes on their back. Because the conditions were so difficult, we began to share resources. Those of us who had more, shared their things with those of us who had less. This is something that you cannot teach people; it is a part of the march, a part of their movement through space (Saisari).

Many women, through the act of walking and talking, began to take on other roles along the journey: they served as mobile nurses caring for the scars and cuts of their fellow comrades with makeshift bandages, or they transformed themselves into surrogate mothers, nurturing hungry or thirsty children. Some women lacked formal nursing skills, but their knowledge of community forms of healing made them medical experts on the trip. These skills prove important in MST settlements, like Pueblos Unidos, where residents live 14 to 15 hours from the closest medical facility. There are no doctors in these communities, and therefore community residents take on medical roles in order to facilitate the

\footnotetext{
${ }^{14}$ See Liebow (1987), Barnes (1969), Stack (1974), and Firth (1970).
} 


\section{REVISTA DE ESTUDIOS BOLIVIANOS}

welfare of the group. This was the case along the journey, as a professional medical staff only visited the demonstrators in major cities.

Throughout the long and painful march, MST members shared their struggles of survival in rural communities of Santa Cruz. Pain, according to Veena Das, is the medium through which a historical wrong done to a person can be represented, taking the form of memory inscribed on the body. The physical pain of the moment - the blistered foot or the marks of cuts and bruises on the legs - become the medium through which memory is created. Many regional scholars have written about the importance of collective memory in building oppositional politics in Bolivia, some have even gone so far as to describe this "collective consciousness" as the politicization of social memory (Delgado 1994). In the case of the Bolivian marchers, these memories vividly captured the sadness associated with losing their jobs to younger, healthier daylaborers, or images of hungry children forced to chew coca to quiet their famished bodies. ${ }^{15}$ "We were tired and hungry. These feelings triggered thoughts about our kids back home. We wondered if they were eating, and if they were eating, what they were eating. We left them in the hands of friends, neighbors, and family members. We hoped they weren't suffering as much as we were along this journey" (Juanita Cortés. Personal interview. August 15 2006). Thus, the organizational structure of the columna also provided the opportunity for comrades to share memories of larger struggles, as the sharing of pain opens up the possibility of the creation of political relationships.

\section{Marching as an Interactive Lesson for the Poor}

MST-Bolivia did not have the financial resources or material means to formally educate their bases on the march, as did their Brazilian counterparts. During a 17 to 20 day march for land reform, MST

\footnotetext{
${ }^{15}$ Nancy Scheper-Hughes argues that embodiment concerns the ways that people come to "inhabit" their bodies so that these become in the very sense of the term habituated. From a kind of phenomenological perspective, all the activities of working, eating, grooming, resting, getting sick, etc. are forms of body praxis and expressive of dynamic social, cultural, and political relations. She suggests that it is easy to overlook the simple observation that people who live by and through their bodies in manual and wage labor - who live by their wits and by their guts - inhabit those bodies and experience them in ways very different from our own. The structure of individual and collective sentiments down to the feel of one's body is a function of one's position in the productive order.
} 


\section{REVISTA DE ESTUDIOS BOLIVIANOS}

participants in Brazil received booklets covering a diverse set of topics related to the national and international political economy: capitalist projects for the restructuring of agriculture via agribusiness, transnational corporations, such as Monsanto, genetic modification of seeds, and the broader implications for family agriculture. These booklets and texts were then used to stimulate important conversations about the future of Brazil's economy and to forge an alternative and popular project for the nation.

MST-Bolivia cannot yet imagine such a formalized structure of education. During their marches, members learn organically, as they talk and travel through regional spaces. In the words of the well-known African revolutionary Amilcar Cabral, "Let those who know a little more teach those who know a little less. We must learn from life, learn among our own people... learn from the experiences of others, but always learn." Such a statement reflects the Bolivian organizers' reality. MST's educational philosophy is a dialectical structure of participation and learning: walking and talking, stopping and eating, and possibly dancing and singing en route to La Paz. As the marchers built relationships in motion (or began to understand the relationship between individual needs and collective struggle), they also negotiated spaces for social and political reform.

The organizational structure or praxis of marching in núcleos, then, created a critical educational space for understanding campesino subsistence battles. One MST organizer stated, while reflecting on the march:

In Bolivia, we do not learn through texts. We could never be like Brazil; it would be impossible to read revolutionary texts. The majority of the people in our movement are illiterate, never taught to read or write formally. We learn about revolutionary politics in action or through movement. We gain a sense of the larger struggle regarding land and territory through the stories of our comrades. And our ideology, MST's political ideology is shaped through our actions (Saisari).

Following up on his point, another MST leader described the march as a school for the landless, "where one learns how to be a leader who never thought he could lead, where one learns how to be a little more 


\section{REVISTA DE ESTUDIOS BOLIVIANOS}

humble through the struggle or sacrifice of walking, where one becomes a little more literate even though he can't read or write (Silvia Rivera. Personal interview. July 30 2007).

Such insights point toward the educational value of narratives of individual struggle and sacrifice. The physical experience of walking while hungry triggered the exchange of stories about the loss of small-scale farming. One woman from Sagrado Corazón shared her story with a woman standing next to her in the columna. The two women did not know one another prior to the march; however, their organization in space provided the opportunity to exchange ideas, reflect upon their lives, and forge a new relationship. Margarita begins:

Things have gotten really bad in the past ten years. Most of us don't have our own land in which to grow produce for our own families. In my case, my husband got very sick with tuberculosis this year. We didn't have health insurance. And if someone doesn't have health insurance and is poor, then their chances of surviving are slim. He died a few months ago and left me all alone. I didn't know how I was going to support my five children. There were days that we didn't have food...I had to find shelter in the gymnasium of a school. We stayed there for a while... until I managed to find a job selling fruits and vegetables in the local marketplace (Margarita Mamani. Personal interview. August 17 2006).

While listening to her story, her spatial partner responds:

I know exactly what you mean. I cannot produce enough food for my family's consumption, either. I have to rent a small plot of land, and then pay for the plot of land from the actual food that I harvest. There are days that I give my children "mate de coca" to kill the hunger pains, so that they stop asking me for food. What else can we do?

Stories of hunger and pain, shared in the columna, forge social relations of meaning. As well, the talk of hunger politicized food as the critical issue. By making private sensations such as hunger public, campesinos turn subsistence struggles, which are often understood as 


\section{REVISTA DE ESTUDIOS BOLIVIANOS}

individual problems, into a collective battle to produce healthy and culturally appropriate food. Beyond the talk of the challenges to subsist, MST organizers inculcated movement ideology through the actual practice of cooking a meal and eating together.

Food practices, which occurred during moments of rest and relaxation, prove central to both the social organization and the building of an alternative political ideology. Everyday activities of food preparation in these transitional moments of pause during the march transform a physical necessity into a deeply meaningful symbolic and communal act. Of equal importance, such practices convert ordinary space into a political place of discourse and resistance, standing against the agro-industry model of food production and consumption.

\section{The Anthropology of Food}

Anthropologists have long been interested in the cultural, structural, and social meanings of particular foods and food practices. Claude LéviStrauss and other structural anthropologists sought to understand "deep structures" that find expression in and through food. Scholars of the 1980 s and 1990s then offered critiques of such isolated, one-dimensional analyses of food, suggesting that structuralists failed to understand regional, national, and global inequalities in relation to food practices across time and space.

More recently, scholars have traced the movement of particular foods, such as sugar, bananas, and coffee, ${ }^{16}$ from the third world to the first in order to understand larger systems and structures of inequality. ${ }^{17}$ Sidney Mintz (1985) analyzes the evolution of sugar from a rare foreign luxury to a commonplace necessity of modern life, and how it changed the history of capitalism and industry. Similarly, William Roseberry (1996) focuses on the complex relationship between new methods of

\footnotetext{
${ }^{16}$ Cynthia Enloe (2000), William Roseberry (1996) and Sidney Mintz (1985) illustrate how everyday commodities (such as bananas, sugar, or even coffee) have a political economic history. By tracing the production, consumption, and distribution of such foods and placing them within a wider historical perspective, they each untangle destructive webs of foreign power and US influence and trace inequality across race, class, and gendered lines.

${ }^{17}$ See Mintz 1985, Enloe 1990, Roseberry 1996, and Striffler 2005.
} 


\section{REVISTA DE ESTUDIOS BOLIVIANOS}

coffee production and consumer taste or preferences for specialty blends. He argues, "The continued success [of gourmet coffees] will depend upon the processes of social and cultural differentiation they mark, even as the social locations of groups of consumers are blurred. It will also depend upon the continued existence, at home and abroad, of a world of exploitative relationships, evidenced in the social relations through which coffee is produced" (Roseberry 774). While tracing the historical lives of commodities from production to consumption illuminates multiple layers of injustice, the act of preparing food as a community can be thought of as resistance to capitalist food systems.

There is a subtle form of education in the practices of cooking and eating that provides insight into cooperative living that is both economic and political, contributing to the development of class-consciousness and socialist values. The act of preparing una olla común (a communal pot from which everyone gets served) is a practice that extends well beyond the individual body, beyond individual sensations and necessities of hunger, to fulfilling the needs of the larger group. Importantly, it is not the actual food that matters, but the practice and structure of preparing a meal, which has embedded in it a hidden code regarding movement ideology. The importance of gendered equality, collective forms of preparation and labor, and redistributing resources all become critical to food traditions and rituals. In the words of an MST organizer, "Whatever we had, we figured out how to put something together to make a meal. It didn't matter if it was the best meal that we had; it just had to fill our stomachs so that we could keep walking. I lost ten kilos on the march. There were people who lost twelve kilos. We didn't eat well, but we ate enough to survive the conditions of the march" (Saisari).

When the columna stopped at a particular location, people divided into distinct work groups or commissions (food, health, security, and political ideology). The work commission called Food and Sustenance mobilized its forces to travel through the designated rest zones in search of food donations such as grains, fruits and vegetables, and sometimes even fish or meat. "They went out to the markets, to distinct social and labor organizations, asking for support. In Cochabamba, informal market vendors, small shop owners, social service organizations, and public university students donated staples in solidarity; they gave large quantities to the national-level movement, and then we would divide that up to the regional bases for food preparation" (Silverio Cusipuma. Personal conversation. Oct. 15 2007). 


\section{Food Rituals as Symbol of Movement Politics-Ideology}

Food preparation along the march is similar to an MST settlement where, according to the movement's official vision, work should be divided equally. ${ }^{18} \mathrm{~A}$ well-known MST quotation is "sin participación, igualdad de las mujeres, no hay socialismo [without participation, equality of women, there is no socialism]." Such a statement, while discursively quite eloquent, does not hold true in practice. There is a consistent joke about women preparing the pot for the entire community. As one MST organizer stated, "Well it is time for the Gringa [referring to me] to use her Usos y Costumbres. ${ }^{19}$ Usa tu derecho como mujer [use your rights as a woman] and cook us all a North American meal for the whole family" (Cusipuma).

This joke provides but one window into a gendered division of labor, where women often prepare the pot of food for the entire movement. This behind-the-scenes physical labor performed by women can be thought of as the backbone of movement politics. As women prepare the food, they transmit ideas about socialism. As one member stated:

It is as if we transmit our ideas about what a society should look like through food preparation. We each throw our ideas into the pot. If capitalism encourages people to buy from large supermarkets and chain stores, we used food from local markets and vendors. If capitalism separates food production from the labor process by encouraging people to buy frozen foods, we forced people to engage in a collective labor process. If capitalism forces people to eat fast, on their way to work or in a rush, we encouraged people to enjoy a meal, to savor the moment. So this new society we want to create

\footnotetext{
${ }^{18}$ Labor is divided equally in terms of responsibility; however, there is still a gendered division of labor. Women cook for the entire group, while men collect firewood, start the fire, and search for food.

${ }^{19}$ Usos y Costumbres refers to the traditional use and distribution of natural resources as a collective cultural right, which was reinforced by a legal amendment to the constitution. In terms of land, indigenous social movements have expanded the state's limited concept of land - understood simply as a factor in agricultural production - to a larger concept of territory as the location for the social reproduction of collective identity (Albro 2006).
} 


\section{REVISTA DE ESTUDIOS BOLIVIANOS}

has to be based on a new set of values. And so my role as one of the representatives of the food commission was to promote these new values through the search for food and the act of preparing a meal (Gregoria Sulka. Personal interview. Dec. 20 2006).

Yet such forms of work are often described as "labors of love," not recognized by leaders and rank-and-file members as "the real political work," but rather extensions of their household duties along the journey. Just like their predecessor, Domitila Chungara (the leader of the housewives' committee Siglo XX in a mining village in Potosí, Bolivia, in the 1970s), these MST campesinas balance everyday work in the domestic sphere, "labors of love," with deep commitment to movement politics.

Through the conscious choice of using organic food, supporting local markets, and cooking together, MST women call into question the spatial logic of capitalism. From the organization of work and labor policies on plantations, to the separation of labor from food production and consumption, to individual choices regarding food preparation, women question and challenge the existing model.

We did challenge the existing model by supporting local vendors; MST members went to the little corner stores and shops, to the peripheral "zonas" to ask for food donations. We refused to support the big business model, steered clear of supermarkets and other large chain stores. And the food we prepared, although it wasn't by any means a balanced meal, it was mostly organic (Margarita Mamani).

Gradually, a new reality was shaped or created through food rituals. These values were literally written or engraved onto space - peripheral rural spaces, small towns and villages - through the process of cooking and eating together.

The act of preparing food, then, in many ways resembled the practice of eating. The marchers used one huge pot called the olla común. The common pot has a long history in rural indigenous communities in the Andes, usually prepared during fiestas and community work projects in order to feed large numbers of people. 


\section{REVISTA DE ESTUDIOS BOLIVIANOS}

More recently, social movements have utilized the common pot as a kind of "moveable feast" in order to support striking workers in the mines and factories. Further, the mobile communal pot is used when many family members accompany their relatives on marchas de sacrificio, like this landless peasant march, in which workers walk for days or even weeks to pressure government officials to pass legislation to protect the rights of workers.

While Catherine Allen (1998) and Mary Weismantel (1988) argue that food can be used to create hierarchy, MST members (despite obvious gendered divisions of labor) use food rituals to erase difference. Allen argues that the order in which individuals receive coca offerings has much to do with their social status. High status individuals should receive $k^{\prime}$ intus (coca offerings) before those of lower status (Allen 105).

Weismantel observes a similar phenomenon in the Ecuadorian Andes, as decisions regarding the order of food distribution indicate one's position within the household. She states that the women not only control the order of serving, but a veritable arsenal of tools for expressing their opinions of those they serve. In practice, the dishes offer yet another scale on which social worth can be measured. While women in Weismantel's household structures played around with power structures and inversed hierarchies by selecting bowl size and portions of soup, MST women rationed the food in such a way as to reinforce the egalitarian values of the organization. They served the elderly and disabled first, women and children second, international volunteers were served shortly after, and then the remainder of the rank-and-file. This provided insight into the culture of the movement: the most vulnerable people, the elderly and the disabled, were valued above all others, and they would be cared for through collective labor practices. Doña Pascuala stated:

I am too old to work. I have arthritis - my joints and legs hurt me now. My children have pretty much abandoned me. That is what happens when your sons marry - their wives become more important than their mother. But MST has become my surrogate family; my brothers and sisters here will take care of me in my old age. I am sure of that. They plant seeds, prepare my plot for harvesting, and help me take my products to local markets. This is the good thing about the organization; we can age and not be 


\section{REVISTA DE ESTUDIOS BOLIVIANOS}

punished for it (María Pascuala. Personal interview. August 10 2006).

Mutual aid relationships, initially built in motion (in columnas), were further enforced and nurtured through this ritualized exchange of food, drink, and discourse. The establishment of social bonds through gifts of food has been a focus of anthropological work (Pritchard, Malinowski, Mauss). In the Andes, however, formalized enactments of reciprocity 20 and exchange also play an important role in the construction and maintenance of social bonds, and the gift of food is considered of prime importance. It did not matter if the food was prepared in the home or on the side of the road; this ritualized exchange of food and utensils solidified relationships. Some MST members did not have the appropriate eating tools, and yet, just as the food was shared from the olla común, so too were the utensils (plates, silverware, and cups). People who actually had utensils ate quickly and passed their plates and forks along in the circle. Once again, those who lacked resources -in this case, utensils - were taken care of by the group.

As people ate and drank in small groups, they also talked about distinct struggles in their communities: how do you organize peasants locally, how do you teach them to move beyond individual needs and desires to the collective, how do you inculcate the value of collective work and labor? These questions filled mealtime with political discourse and purpose. MST members and leaders often commented on the individual survival strategies of many compañeros and their frustrations associated with organizing poor peasants into MST núcleos. Just as cooking a meal is a process, so too is the building of a larger, counterhegemonic movement. In this instance, the microscopic process of food preparation, exchange, and consumption aided the movement's larger intention to enforce policies of land redistribution and teach people in process the benefit of collective title, work, and labor.

\footnotetext{
${ }^{20}$ Mary Weismantel (2001) argued that scholars interested in the Andes, among them Maurice Godelier, Nathan Wachtel, and John Murra (1975), wedded Mauss's insights to Marx's. They made a conceptual link between Andean precapitalist intensive agropastoralism as a mode of production, and reciprocity - the gift economy - as a form of exchange. The result was a new understanding of the Incas, who famously began their relations with a newly conquered people by showering them with gifts.
} 


\section{REVISTA DE ESTUDIOS BOLIVIANOS}

Through food preparation and rituals, MST provided the tools for campesinos to criticize their lives and start the process of altering their social reality. In many ways, like the spatial structure of the columnas, the social organization of food practices (the division of labor and the ritualized acts of eating together) was a popular method of teaching, learning, and participating. Through this process, the landless were transformed from a laboring workforce into active citizens, demanding both political rights and land entitlement. Mundane practices of walking, talking, and eating illuminated for campesinos the connections between the everyday subsistence battles, food production and consumption, and the recuperation of indigenous land and territory. They marked this rural space, through discourse and food, as their own, a kind of politicized territory belonging to MST.

\section{An Upside-down World: Occupying Central Plazas, Re-Producing and Re-inventing Place}

Just as they marked rural or isolated provincial towns with their eating practices, MST's occupation of city centers transformed plazas from public urban space into sites of resistance. The famous MST slogan, "ocupar, resistir, producir" [occupy, resist, and produce], moved from discourse to practice as thousands of people approached their penultimate staging ground in Cochabamba, the central Plaza 14 de Septiembre. MST's energy literally exploded into and onto the very spaces that symbolized historic and contemporary inequality: perfectly preserved colonial-style plazas and architecture, private capital investments in the form of trendy new businesses, and $21^{\text {st }}$-century forms of spatial segregation and surveillance. Through the occupation of city centers, MST restructured historic and contemporary patterns of spatial exclusion with staged theater and dance.

Daniel Goldstein traces Cochabamba's uneven history of urban development throughout the $20^{\text {th }}$ century, which took the form of architectural solutions to migration and poverty. The impulse to produce an ordered and modern city through physical design had much to do with the white, elite fears of mass indigenous migrations to city centers. A series of migrations in the 1950s and 60s disrupted the modernist idea, and by the 1980s and 90s, the architectural impulse to produce an ordered, utopian city through physical design completely failed. The 


\section{REVISTA DE ESTUDIOS BOLIVIANOS}

urban fabric of the city was more disordered than ever, and the city adopted exclusionary politics in response to vast zones of unregulated migrant settlements on the south side of Cochabamba.

The core of the city, then, was to be protected while the migrant barrios were ignored. The old city symbolized a space of modern economic activity but the periphery was a site of sprawling urban poverty, unsanitary conditions, rising crime rates and overcrowded housing. If the indigenous poor have been systematically pushed out of the city proper to urban shantytowns, why do they take over city centers as acts of resistance?

Seizing city centers can be understood as a spectacular performance, transporting and educating people in urban communities. Embodied performances, such as song, dance, and speeches in the plaza, play a central role in producing and transferring knowledge ${ }^{21}$. In the words of one MST leader, "the true MST performer is the one who brings from his breast the smell and the color of his land, the mark of blood of the deaths that he has witnessed, and the certainty of his struggle lives on" (Luis Salvatierra. Personal interview. Sept. 15 2006).

This is the goal of the MST misticas in the plazas, to transport the struggles of the campesinos to urban small-scale shop owners, street vendors, and restaurant workers. Through songs and speeches, they reenact rural subsistence battles in a city center where food circulates in abundance, and where stable housing structures protect people from the cold of winter. As informal workers, businessmen, and even some professionals gathered in the plaza 22 to watch the unfolding performance, they began to shout and cheer in solidarity. MST, through these místicas, transported their struggles to new sites and spaces.

Sometimes, these dramas can become big and bold. As MST and other indigenous groups seized the Plaza 14 de Septiembre, they also infused the main square with dynamic highland Andean cultural forms and practices. Such cultural practices, which had been pushed to the margins, now occupied center stage as indigenous people claimed

\footnotetext{
${ }^{21}$ See Taylor 2003, Conquergood 2002, and Johnson 2003.

${ }^{22}$ Some of the people present in the plaza were merely spectators; others were part of a web of social service and NGO support. By and large, however, many people could not get to work because the roads were blocked and got swept up in the festivities.
} 


\section{REVISTA DE ESTUDIOS BOLIVIANOS}

citizenship rights through radical land redistribution. The sound of highpitched charango music, traditional huayno rhythms, and Quechua lyrics all marked this space. Some danced in small circles to traditional Andean dances. Many protesters also carried the wiphala flag, which symbolized the call for national cultural sovereignty (Stephenson 2002). MST immediately hung several banners on the municipal buildings surrounding the colonial plaza, which read: La Tierra es vida, no a la mercantilización [Land is Life, Say No to Land Privatization]. They placed these makeshift banners next to the traditional red MST flag, which, in the words of a rank-and-file member, "is a potent symbol of the blood that must be shed in order to recover indigenous land and territory." Through such performances, they formed alliances with the urban world and built their bases through popular participation as more and more people joined their march.

\section{The Final Staging Ground}

While Cochabamba served as a critical space in which to build the urban bases of their movement, El Alto represented the final climactic moments. On November 27, approximately 2,000 protestors arrived in $\mathrm{EI}$ Alto, a predominantly indigenous, Aymara city of approximately 800,000 people on the upper edge of La Paz. From an altitude of 13,400 feet, the people of El Alto look down onto the adjacent city of La Paz, which sits in a crater-like bowl high in the Andes Mountains. In this overcrowded and congested city, one can barely move through the streets leading to La Ceja, the main market. The sidewalks are filled with vendors selling products ranging from electronic items to everyday household goods. Rundown hotels and alojamientos [motels] shape the rather grim cityscape. Homeless people sleeping on the curb are a permanent fixture. Buses line up in an assembly-line fashion, waiting for passengers to board. Black smog from stationary vehicles creates dark circles in the thin air, making it difficult to breathe. Garbage and trash line the streets and there is no running water or sewage system. People simply lift their polleras to urinate on the side of the road. The graffiti on the walls, "Basta al reformismo del MAS. Revolución maoista ahora," [Enough of the reformism of Evo Morales' MAS, We want a Maoist Revolution Now] encapsulates the claustrophobia of the streets, the intense poverty, and lack of public services in satellite cities. El Alto has been described as ground zero for many protest movements, especially national-level 
demonstrations to reclaim and recuperate natural resources, such as water, gas, and land. This final site on the national map serves as the launching pad for governmental negotiations.

Aymara and Quechua community leaders and neighborhood organizations joined MST in this historic march for land and territory. It was at this point that the protest scene grew from 2,000 to nearly 30,000: the miners dressed in their classic garb with hard top hats and sticks of dynamite, mothers dressed de pollera with children on their backs wrapped tightly into colorful Andean shawls, and the many landless - some barefoot, some with warn-out abarcas - who walked from Oruro and Potosí braved the cold air of El Alto. In the midst of wiphalas rippling in the wind and the sound of pututus (ceremonial horns), the two groups, lowland Indians and highlanders, sealed a solidarity pact with the ritual sacrifice of a llama.

\section{Re-Territorilizing Power through Claiming National Space}

At 5:00 AM the next morning, the marchers organized into their columnas in order to descend into La Paz's main plaza, the Plaza San Francisco. As they walked down the slope, they sang "Que se acabe, que se acabe esta marchasa" [It will finish soon, it will finish, this long march]. They arrived at their final destination at rush hour, cheered on by the thousands who lined the city streets to welcome them. ${ }^{23}$ The old drummer, who had led the entire march dropped to his knees, kissed the ground, and collapsed, exhausted. It was at that moment that the crowd broke into song. The protesters sang the Bolivian national anthem, placing emphasis on the chorus: "De la Patria, el alto nombre, en glorioso splendor conservemos. $Y$ en sus aras de nuevo juremos: iMorir antes que esclavos vivir! iMorir antes que esclavos vivir! iMorir antes que esclavos vivir! [From our country, in a high-pitched voice, in glorious splendor we proclaim: we will die before we live and work as slaves]." The song

\footnotetext{
${ }^{23}$ However, not everyone was thrilled with this massive demonstration. Many complained that they could not get to work because the streets were closed off, while other paceños spoke of "bloqueo fatigue" or the fact that they were tired of daily road blocks.
} 


\section{REVISTA DE ESTUDIOS BOLIVIANOS}

foreshadowed what was to come: civil disobedience in the very heart of the legislative and executive seat of power. Further, this occupation of the plaza and the subsequent singing of the national anthem illustrated the impermanence of space. As indigenous Bolivians -as the original inhabitants of this space- they were the first citizens of the land, and their homes and communities must be returned in order to decolonize the nation-state.

Such a powerful performance of pan-indigenous solidarity and nationalistic sentiment led to a public declaration by president Evo Morales to pass the New Agrarian Reform Law. He asserted, in front of the massive crowd, "This lucha for land and territory is the same as those of our ancestors of Tupac Katari, and we are still in this fight. We need to make this proposal legal today in order to begin to recover land that belongs to our ancestors. We will take back latifundio land...I am part of this struggle, I am part of you all....and I state, actually I declare before all of you, that we will put an end to the latifundio improductivo." As Nancy Postero (2007) recently argued, Evo Morales' public discourses, while often evoking utopian visions of Andean culture, always serve a particular function -they negotiate spaces for social and political reform. In this particular instance, by evoking the struggle of his Inca ancestors, Morales stood in solidarity with the indigenous campesino movement and encouraged the protestors to continue on to the Senate. Similar to the místicas performed by MST in public plazas, Evo Morales, as President of the republic, used performance to mark national space with meaning and open up a new arena for radical political change and agrarian reform.

From the Plaza San Francisco, the massive crowd broke down into columnas one last time in order to seize the Plaza Murillo, the center of cultural and political power. As soon as they arrived, a well-known leader of the indigenous organization CIDOB from Santa Cruz proclaimed, "We are staying here in the Plaza Murillo. We aren't going anywhere until these changes are passed. We are exhausted, sure, but we are here to reclaim our rights from those land speculators who have taken our lands all over the country," said Natalio Izaguirre, who hiked 18 days from his small village near Potosi, about 260 miles to the south. 


\section{REVISTA DE ESTUDIOS BOLIVIANOS}
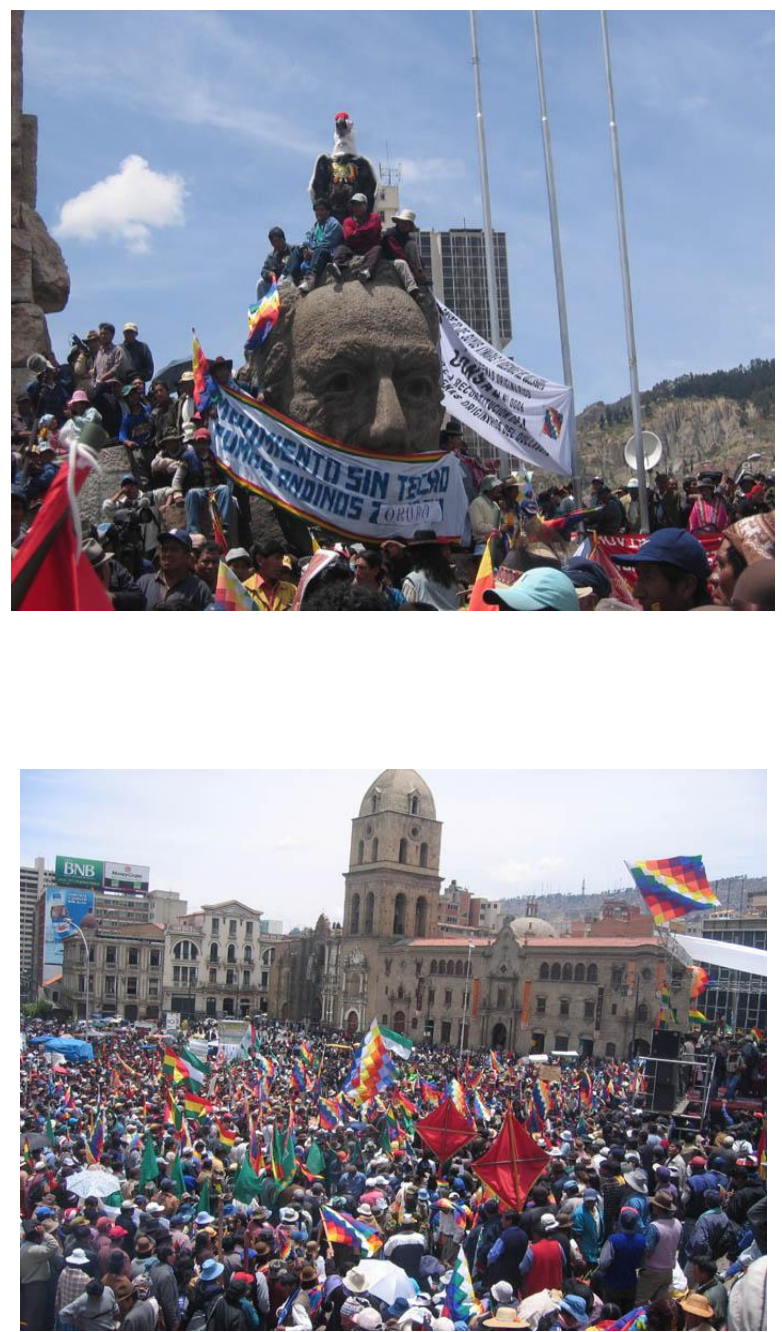

Aerial shots of campesinos flooding the Plaza San Francisco Source: Video Urgente 


\section{REVISTA DE ESTUDIOS BOLIVIANOS}

From the Plaza San Francisco, the massive crowd broke down into columnas one last time in order to seize the Plaza Murillo, the center of cultural and political power. As soon as they arrived, a well-known leader of the indigenous organization CIDOB from Santa Cruz proclaimed, "We are staying here in the Plaza Murillo. We aren't going anywhere until these changes are passed. We are exhausted, sure, but we are here to reclaim our rights from those land speculators who have taken our lands all over the country," said Natalio Izaguirre, who hiked 18 days from his small village near Potosí, about 260 miles to the south.

The massed marchers remained in the plaza long after sunset. Some chewed coca for energy, while others sang revolutionary songs and danced into the night. Through their Andean dances, stories, and tales in the Plaza Murillo, they used highland indigenous culture as a conduit for re-ordering and cleansing Bolivian society of the stain of colonialism, which they believe has only been further tainted by the evils of capitalism and neoliberalism ${ }^{24}$. Through occupying the very heart of political and legislative power, they began to infuse, mark, and redefine national space with an alternative vision of an "indigenous counter-public sphere" (Stephenson 2002). They literally turned the plaza into a tent settlement, thus galvanizing national attention and laying down roots in the very heart or center of power. The 30,000 people refused to move until they received a written contract; they wanted a statement confirming a new kind of agrarian reform, not a minimalist or conformist effort like the agrarian reform bill of 1953 , but a radical change.

As they marked this space culturally, the protestors also transformed the legislative and executive bodies of government through a spectacular demonstration of popular participation. The senators could not ignore the sheer number of people camping in the Plaza Murillo, and so the new agrarian reform law finally passed through the Senate that

\footnotetext{
${ }^{24}$ See Postero 2007, and Rivera Cusicanqui 1992.
} 


\section{REVISTA DE ESTUDIOS BOLIVIANOS}

very night. ${ }^{25}$ This act transformed grassroots ideas into critical legislation which would benefit the poor as opposed to the wealthy, and which would begin to undo a history of unequal land holding patterns. MST and other social movements "do not only want to be recognized by the state; they want their president to enact what philosopher Nancy Fraser calls a [radical] politics of redistribution" (Postero 22). Recognition has been meaningful in the past, but MST realized that national and international recognition was not enough; true dignity and prosperity must be tied to significant material and structural change.

\section{Conclusions}

What, exactly, happened on this month-long protest march? In their swift and steady movement through the national landscape, MST built a national-level counter-hegemonic movement, and they succeeded in liberating space and time from their materializations of the moment. They constructed an alternative and mobile vision, a vision that stood against the neoliberal model of unbridled capital accumulation and white domination of indigenous peoples and cultures, the use of slave-labor conditions, land grabbing, and fraudulent speculative practices. In the backwoods, they constructed an ideology that challenged an agribusiness model of development through their own food practices and eating -through their network of relationships with small-scale market vendors, they provided healthy food for poor people. By cooking together, eating together, and singing in public plazas, indigenous people filled these spaces with social, cultural, and political meaning and carried an important agenda to the seat of power. They took their proposal, which threatened to alter the age-old colonial structure, all the way to La Paz.

\footnotetext{
${ }^{25}$ Oftentimes, mass mobilizations like the most recent march for land and territory prove a critical strategy for meeting the demands of the masses and passing critical legislation through the senate. The attention of mass media and international press focused not only on Bolivia, but stories also focused on the pressing problem of land redistribution for poor people. Many of the senators realized that by ignoring the demands of the majority indigenous population, they would only create greater problems. The pressure from international community forced swing-senators to vote affirmatively for the new agrarian reform bill.
} 


\section{REVISTA DE ESTUDIOS BOLIVIANOS}

The signing of this law into action created tensions and reverberations throughout the country. In the words of an MST member:

The right reacted very strongly to the passing of this new agrarian reform law. They were pissed that they lost the law, which was really their law. They lost their economic and political power with the passing of this critical legislation. And maybe they lost their legitimacy; people didn't really respect their opinion anymore. It was the masses, the populist movement of "indigenas" and "originarios" that were now defining how politics should be run, not a select group of elites.

The right organized a series of spectacular events in response to the passing of this legislation such as protest marches, hunger strikes, and a cabildo [town meeting]. Space, once again, served as a critical analytic theme in building and shaping counter-movement politics. Facing the erosion of their economic and political power, regional elites use cultural performance in particular sites and locations, such as the main plaza, the Christ statue, and distinct neighborhoods, in order to re-assert their symbolic and material lordship over the territory of Santa Cruz.

\section{Works Cited}

ALBRO, Robert. 2006. "The Culture of Democracy and Bolivia's Indigenous Movements." Critique of Anthropology 26/4 (2006): 387-410.

---. 2005. "The Water is Ours, Carajo! Deep Citizenship in Bolivia's Water Wars." Social Movements: An Anthropological Reader. June Nash, ed. Oxford: Blackwell Publishing Press. 249-271.

ALLEN, Catherine J. 1988. The Hold Life Has: Coca and Cultural Identity in an Andean Community. Washington: Smithsonian Institution Press.

APPADURAI, Arjun. 2002. "Deep Democracy: Urban Governmentality and the Horizon of Politics." Public Culture 14/1 (2002): 21-47.

BARNES, John A. 1969. "Networks and Political Processes" Social Networks in Urban Situations. J.C. Mitchell, ed. Manchester: Manchester University Press. 51-76. 


\section{REVISTA DE ESTUDIOS BOLIVIANOS}

BASTIEN, Joseph W. 1978. Mountain of the Condor: Metaphor and Ritual in an Andean Ayllu. St. Paul, MN: West Publishing Co.

BOURDIEU, Pierre. 1984. Distinction: A Social Critique of the Judgment of Taste. Richard Nice, trans. Cambridge, MA: Harvard University Press.

---. 1980. The Logic of Practice. Richard Nice, trans. Stanford, CA: Stanford University Press.

--- 1977. Outline of a Theory of Practice. Richard Nice, trans. Cambridge, MA:

Cambridge University Press.

BRUSH, Stephen B. 1977. Mountain, Field and Family: The Economy and Human Ecology of an Andean Village. Philadelphia: University of Pennsylvania Press.

CABRAL, Amilcar. 1979. Unity and Struggle: Speeches and Writings. New York: Monthly Review Press.

CONQUERGOOD, Dwight. 2002. "Performance Studies Interventions and Radical Research.” The Drama Review 46/2 (2002): 145-156.

---. 1991. "Rethinking Ethnography: Towards a Critical Cultural Politics." Communication Monographs 58 (1991): 179-194.

---. 1988. "Health Theatre in a Hmong Refugee Camp: Performance, Communications, and Culture." The Drama Review 32/3 (1988): 174-208.

---. 1985. "Performing as Moral Act: Ethnical Dimensions of the Ethnography of Performance." Literature in Performance. 5/2 (1985): 174-208.

CORTÉS, Eulogio. 2007. Personal interview. August 25, 2007.

CORTÉS, Juanita. 2006. Personal interview. August 152006.

CUSIPUMA, Silverio. 2007. Personal conversation. Oct. 15. 2007.

DAS, Veena. 1996. "Language and Body: Transactions in the Construction of Pain." Daedulus 120/1 (1996): 30-55.

DE CERTEAU, Michel. 1984. The Practice of everyday life. Steven Randall, trans. Berkeley: University of California Press.

DELEUZE, Gilles and Félix Guattari. 1984. Anti-Oedipus: Capitalism and Schizophrenia. London: Athlone Press.

DELGADO, Guillermo. 1994. "Ethnic Politics and the Popular Movement" Latin America Faces the Twenty-first Century: Reconstructing a Social Justice Agenda. Susanne Jonas and Edward J. McCaughan, eds. Boulder, CO: Westview Press. 78-88.

ENLOE, Cynthia. 2000. Bananas, Beaches, and Bases: Making Feminist Sense of International Politics. Berkeley: University of California Press. 


\section{REVISTA DE ESTUDIOS BOLIVIANOS}

FIRTH, Raymond.1970. Families and Their Relatives: Kinship in a Middle-Class Sector of London. New York: Humanities Press.

GOLDSTEIN, Daniel. 2004. The Spectacular City: Violence and Performance in Urban Bolivia. Durham, NC: Duke University Press.

GRAMSCI, Antonio. 1969. Selections from the Prison Notebook. New York: International Publishers.

HARVEY, David. 2004. Brief History of Neoliberalism. Oxford: Oxford University Press.

---. 2003. The New Imperialism. Oxford: Oxford University.

---. 2000. Spaces of Hope. Berkeley: University of California Press.

JOHNSON, Patrick. 2003. Appropriating Blackness: Performance and the Politics of Authenticity. Durham, NC: Duke University Press.

KOHL, Benjamin. 2003. "Restructuring citizenship in Bolivia: El Plan de Todos." International Journal of Urban and Regional Research. 27/2 (June 2003): 337351.

LEFEBVRE, Henri. 1991. The production of space. Donald Nicholson-Smith, trans. Oxford: Basil Blackwell.

LEVI-STRAUSS, Claude. 1969. The Raw and the Cooked: Introduction to a Science of Mythology. New York, NY: Harper and Row.

LIEBOW, Elliot. 1967. Tally's Corner: A Study of Negro Streetcorner Men. Boston, MA: Little, Brown.

MAMANI, Juan. 2007. Personal interview. August 152007.

MAMANI, Margarita. 2006. Personal interview. August 172006.

MAYER, Enrique. 2002. The Articulated Peasant: Household Economies in the Andes. Boulder, CO: Westview Press.

---. and Ralph Bolton, eds. 1977. Andean Kinship and Marriage. Washington, D.C.: American Anthropological Association.

MINTZ, Sidney. 1985. Sweetness and Power: The Place of Sugar in Modern History. New York: Penguin Books.

MURRA, John V. 1978. La organización económica y política del estado Inca. Mexico: Siglo XXI.

---. 1975. Formaciones económicas y políticas del mundo andino. Lima: Instituto de Estudios Peruanos.

ORTEGA, Daniel. 2006. Personal interview. Oct. 152006. 


\section{REVISTA DE ESTUDIOS BOLIVIANOS}

PACHECO, Diego and Walter Valda. 2003. La tierra en los valles de Bolivia. Apuntes para la toma de decisiones. La Paz: Fundación TIERRA.

PASCUALA, María. 2006. Personal interview. August 102006.

POSTERO, Nancy. 2007. "Andean Utopias in Evo Morales's Bolivia." Latin American and Caribbean Ethnic Studies 2/1 (2007): 1-28.

RIVERA, Silvia. 2007. Personal interview. July 302007.

RIVERA CUSICANQUI, Silvia. 1992. Ayllus y proyectos de desarrollo en el norte de Potosí. La Paz: Aruwiyiri.

ROSEBERRY, William. 1996. "The Rise of Yuppie Coffees and the Reimagination of Class in the United States." American Anthropologist 98/4 (1996): 762-775.

---. 1989. Anthropologies and Histories: Essays in Culture, History, and Political Economy. New Brunswick, NJ: Rutgers University Press.

SAISARI, Silvestre. 2007. Personal interview. July 202007.

SALVATIERRA, Luis. 2006. Personal interview. Sept. 152006.

SCHEPER-HUGHES, Nancy. 1992. Death Without Weeping: The Violence of Everyday Life in Brazil. Berkeley : University of California Press.

SOLÓN, Pablo. 1997. ¿Horizontes sin tierra? Análisis crítico de la Ley INRA. La Paz: CEDOIN.

STACK, Carol. 1974. All Our Kin: Strategies for Survival in a Black Community. New York: Harper and Row.

STARN, Orin. 1993. "Rethinking the Politics of Anthropology: The Case of the Andes." Current Anthropology 35/1 (1993): 13-28.

---. 1992. "Missing the Revolution: Anthropologists and the War in Peru." Rereading Cultural Anthropology. George E. Marcus, ed. Durham, NC: Duke University Press. 152-180.

STRIFFLER, Steve. 2005. Chicken: The Dangerous Transformation of America's Favorite Food. New Haven, CN: Yale University Press.

STEPHENSON, Marcia. 2002. "Forging an Indigenous Counterpublic Sphere: The Taller de Historia Oral Andina in Bolivia." Latin American Research Review 37/2 (2002): 99-118.

SUÁREZ, Rosalita. 2007. Personal interview. July 222007.

SULkA, Gregoria. 2006. Personal interview. Dec. 202006.

SULkA, Ponciano. 2006. Personal interview. June 302006. 


\section{REVISTA DE ESTUDIOS BOLIVIANOS}

TAYLOR, Diana. 2003. The Archive and the Repertoire: Performing Cultural Memory in the Americas. Durham, NC: Duke University Press.

URIOSTE, Miguel. 2006. The Agrarian Revolution of Evo Morales. La Paz: Fundación TIERRA.

VERA, Silverio. 2006. Personal interview. June 32006.

WEISMANTEL, Mary. 2006. "Ayllu: Real and Imagined Communities in the Andes." The Seductions of Community: Emancipations, Oppressions, and Quandaries. Gerald W. Creed, ed. Santa Fe, NM: School of American Research Press. 77-100.

---. 2001. Cholas and Pistachos: Stories of Race and Sex in the Andes. Chicago, IL: University of Chicago Press.

---. 1998. Food, Gender, and Poverty in the Ecuadorian Andes. Prospect Heights, IL: Waveland Press.

WOLFORD, Wendy. 2000. "Families, Fields, and Fighting for Land: The Spatial Dynamics of Contention in Rural Brazil." Mobilization: An International Quarterly. 8/2 (June 2003): 157-172.

\section{(cc) BY-NC-ND}

This work is licensed under a Creative Commons AttributionNoncommercial-No Derivative Works 3.0 United States License. 